\title{
Goldfish Erythrophoroma
}

National Cancer Institute

\section{Source}

National Cancer Institute. Goldfish Erythrophoroma. NCI Thesaurus. Code C134562.

A red-pigmented tumor that occurs in a goldfish. 